\title{
Tax Interactions among Belgian Municipalities: Does Language Matter?
}

\author{
MARCEL GÉRARD \\ HUBERT JAYET \\ SONIA PATY
}

CESIFO WORKING PAPER NO. 2558

CATEGORY 1: Public FinANCE

FEBRUARY 2009

\footnotetext{
An electronic version of the paper may be downloaded

- from the SSRN website:

www.SSRN.com

- from the RePEc website:

- from the CESifo website:

www.RePEc.org

www.CESifo-group.org/wp
} 


\title{
Tax Interactions among Belgian Municipalities: Does Language Matter?
}

\begin{abstract}
This paper tests the existence of strategic interactions among municipalities using a panel of Belgian local tax rates from 1985 to 2004. A special emphasis is put on the role of the language spoken in the various municipalities. Our results first confirm previous findings for Belgium suggesting that municipalities interact with each other over the two main local tax rates, the local surcharge on the (labour) income tax rate and the local surcharge on the property tax. Using tools of spatial econometrics and an original methodology for specifying weights matrices, we find out that municipalities are sensitive to tax rates set by their close neighbours only. We also reject the hypothesis that the language does not matter: in the within model and for the local income tax rate, the intensity of interactions is shown to be lower between municipalities speaking different languages than between municipalities speaking the same language. That observation is particularly relevant for today Belgium and might be viewed as a contribution to the ongoing debate on the regionalisation or partial decentralization of some taxes.
\end{abstract}

JEL Code: H24, H31, H71.

Keywords: tax interactions, panel data, spatial econometrics, local tax rates, tax competition, yardstick competition.

\author{
Marcel Gérard \\ Louvain School of Management \\ FUCaM \\ Chaussée de Binche, 151 \\ Belgium - 7000 Mons \\ marcel.gerard@fucam.ac.be
}

Hubert Jayet

EQUIPPE / University of Lille

France - 59655 Villeneuve d'Ascq Cedex

hubert.jayet@univ-lille1.fr
Sonia Paty

EQUIPPE / University of Lille

France - 59655 Villeneuve d'Ascq Cedex

sonia.paty@univ-lille1.fr

This paper has been presented in various conferences during the year 2008 and we are indebted to the colleagues who provided us with comments, remarks and suggestions especially Thiess Buettner and Craig Brett. 


\section{Introduction}

During the last two decades, a large theoretical literature on tax competition has developed following the seminal papers of Zodrow and Mieszkowski (1986), Wilson (1986), Wildasin (1988) - see Wilson (1999) for a survey. The basic argument is that jurisdictions interact with their neighbours to attract a mobile activity or a mobile tax base. There is an alternative theoretical explanation for local authorities being affected by their competitors when they set their tax rates. It is based on the idea that citizens evaluate the performance of their incumbent leaders by comparing their public decisions with those set by the nearby local authorities. This theoretical literature on "yardstick competition" has been developed a.o. by Salmon (1987) and Besley and Case (1995).

Although theoretical literature on strategic interactions is quite voluminous, empirical studies are quite recent. Most papers concentrate on tax interactions among local jurisdictions within a country or among states within a federal country - see Brueckner, (2003) for a survey. These models are usually implemented empirically by means of estimation of a fiscal reaction function, where the optimal tax rate in a jurisdiction depends on the tax rates in nearby jurisdictions (Revelli, 2005). Most papers including those of Ladd (1992), Case (1993), Brett and Pinske (2000), Buettner (2001), Heyndels and Vuchelen (1998), Brueckner (1996), Brueckner and Saavedra (2001), Richard, Tulkens and Verdonck (2002), Feld and Reulier (2005), Feld, Josselin and Rocaboy (2003), Bordignon, Cerniglia and Revelli (2003), Solé-Ollé (2003), Leprince, Madiès et Paty (2007), Charlot et Paty (2007) find empirical evidence of positive interactions among sub-national governments using various data sets. Our paper is mainly in line with this strand of literature by using a panel of Belgian local tax rates data from 1985 to 2004.

Our contribution is twofold. First, we find that Belgian municipalities interact with each other on the two main local tax rates, the local surcharge on the income tax and the local surcharge on the property tax. That first result is consistent with the results obtained by previous studies, especially Heyndels and Vuchelen (1998), which proposes a cross section analysis, and Richard, Tulkens and Verdonck (2002), which, on the same period, uses a 
dynamic model where the slope of the reaction function is not directly estimated. Using tools of spatial econometrics and an original methodology for specifying weights matrices, we find out that municipalities are sensitive to tax rates set by their close neighbours only.

Second, we explore the effects of the proximity in terms of language on the empirical evidence of tax interdependence. Then, we reject the hypothesis that the language does not matter for interactions among nearby jurisdictions. Especially, for the local income tax rate, in the within model, the intensity of interactions is shown to be lower between municipalities speaking different languages than between municipalities speaking the same language - the three languages spoken in Belgium are Dutch, French and German. That observation is particularly relevant for today Belgium and might be viewed as a contribution to the ongoing debate on the regionalisation of some taxes.

That reflects the observation that residents' location choice is influenced by the language spoken in the municipality. A Belgian citizen usually prefers living in a municipality where the residents speak his own language, in order to avoid costs induced by the unavailability of schools, sport and cultural facilities in his own language, or by the need to translate official document received in another language. A policy-maker who fears the mobility of its tax base (the residents) will thus pay more attention to the fiscal choices of the nearby municipalities that share the same language. Moreover, an incumbent who does not fear the residents' mobility but wants to be re-elected is likely to take as a yardstick the fiscal choices of the nearby municipalities that share the same language because the access to information on fiscal conditions is supposed to be easier between such municipalities - e.g. Belgian newspapers, as to national news, are rather focused on their own language community.

Notice that the fact that the difference in terms of interaction occurs for the local income tax, which is levied on a residence principle, rather than for the tax on immovable property, levied on a source base, is per se an interesting result: as we will repeat in the conclusion, that results supports the view that providing the regions with more fiscal autonomy is less likely to generate externalities if that autonomy focuses on a tax levied according to the residence principle and related to the personal taxpayer location decision than on a tax 
levied according to the source principle and related to the location decision of taxpayer's wealth.

The paper is organized as follows. The next section presents the empirical design. The results are shown in section 3 and the last section concludes.

\section{Empirical Design}

In this section we provide some useful information as to Belgium before discussing the specification of our model and presenting the data set that we use.

\subsection{Belgium, municipalities and local taxation}

Belgium is a multilevel government country ${ }^{2}$, a federation consisting of three regions and three communities. Regions - Flanders, Wallonia and Brussels - are basically in charge of matters related to the territory, like economic development, employment policy, infrastructure and the supervision of municipalities. Communities - the Dutch, French and German-speaking communities - are responsible for issues related to persons, like education and health. Each region and each community has its own government and parliament though Flanders and the Dutch-speaking communities have been merged. Since March 2008, the Walloon Region and the French-speaking Community have the same Minister-President. According to the Belgian Constitution, the residual power belongs to the regions and communities. Even if they are not competent for territorial matters, the authority of communities corresponds to a territory, that of the Dutch-speaking to Flanders and Brussels, and that of the French-speaking one to Wallonia and Brussels as well; the authority of the small German-speaking community is on a series of municipalities attributed to Belgium after the first world war and located in Wallonia.

In today Belgium, the corporate income tax and the value added tax are only federal; the personal income tax is mainly federal, but regions are permitted to add positive or negative

\footnotetext{
${ }^{2}$ For details, see e.g. Gérard (2002).
} 
surcharges, and municipalities as well - see below; the immovable property tax goes to the regions which decide of its rate but municipalities add surcharges. Regions are mainly financed by transfers from the federal government and by regional taxes as well, while communities are essentially financed by transfers.

Belgium also consists of ten provinces and 589 municipalities. In the sequel of the paper we focus on municipalities. Their major expenditure categories include culture and education, police, welfare and transport infrastructure and general administration. They levy numerous local taxes and receive the revenue of the surcharges mentioned above so that taxation accounts for more than 40 per cent of local revenues. The remaining comes from transfers from the regional authorities. However, two taxes, the local income tax and the local property tax, are their major sources of revenue, accounting for 80 per cent of municipal tax revenues; the former accounting for more than the latter in a ration between 1.7 to 1 and 1.2 to 1 depending on the region. Both local taxes are surcharges freely determined by municipalities:

- the local income tax is a surcharge on the federal income tax paid by individuals, the rate of the surcharge is between 0 and 10 per cent; in practice this is a tax on labour income (savings income is taxed separately),

- the local property tax is a surcharge on the regional property tax; its base, also defined at federal level, is an imputed income on immovable property; that tax is paid by all the taxpayers - individuals, companies, charities... - on the basis of the location of the property.

Notice that the regional property tax amounts to 1.25 per cent in Brussels and the Walloon Region, and to 2.5 per cent in the Flemish Region, of the imputed income on immovable property; the local surcharge varies between 293.75 and 5,750 per cent of the regional tax. It is important to say that the location of the property determines the place where the tax is to be paid; as an illustration, an individual resident of municipality $A$ which owns a real property in municipality B will pay the local income tax on his labour income in municipality A but the local property tax in municipality B. This explains why, on the sea side, two municipal councils elected by resident taxpayers have decided for a zero local income tax 
rate, charging the burden of local tax revenue on the property tax paid by non-resident owners, or users, of the houses and flats.

Each municipality has thus a council elected every six years by residents who vote on lists of candidates presented either by political parties - those also active at regional and federal level - or by local groups, e.g. "list of the mayor", usually affiliated with one or some of the parties; each list has municipal counsellors in proportion to the number of votes obtained. Then a majority contract is passed within the municipal council; on that base the mayor is designated by the Region and his deputies, in charge of specific fields like finance, education, culture... are elected by the council. The mayor and his deputies form the municipal college, the executive of the municipality.

Finally, the main factors of mobility within Belgium are the location of the workplace, though many Belgian residents commute a lot for reaching their workplace, and the price and size of grounds and houses; as explained above, the residents' localisation choice is also influenced by the language spoken in the municipality.

\subsection{Empirical specification}

\subsubsection{The econometric model}

Our aim is to test the existence of strategic interactions among municipalities and to find the effect of linguistic proximity on this interdependence. Both theoretical models of tax and yardstick competition have the same empirical predictions that jurisdiction $i$ fiscal decisions in year $t, \tau_{i, t}$, depend on $i$ 's own neighbours' corresponding fiscal decisions, $\tau_{j, t}$, and on $i$ 's own socio-demographic characteristics $X_{i, t}$. Using a linear formulation, we obtain the following model

$$
\tau_{t}=\alpha+W(\rho) \tau_{t}+X_{t} \beta+\eta+\varepsilon_{t}
$$


where, $\tau_{t}=\left(\tau_{1, t}, \ldots, \tau_{N, t}\right)^{\prime}$ is the vector of fiscal decisions by all the jurisdictions at date $t, X_{t}$ is the matrix of the socio-demographic characteristics and $W(\rho)$ is a matrix of spatial weights. This matrix depends on $\rho$, which is a vector of parameters measuring the intensity of interaction. Moreover, $W(0)=0$ (The specification of $W(\rho)$ will be examined later on, section 2.2.2). The vector $\eta_{t}=\left(\eta_{1}, \ldots, \eta_{N}\right)^{\prime}$ is a vector of fixed municipal effects, taking into account the impact of the unknown time-invariant factors influencing the tax rates.

Stacking over periods $t=1, \ldots, T$, and using Kroneker products, Equation (1) may also be written as

$$
\tau=\alpha+\left[I_{T} \otimes W(\rho)\right] \tau+X \beta+\left[e_{T} \otimes I_{N}\right] \eta+\varepsilon
$$

where $I_{T}$ (resp. $I_{N}$ ) is the identity matrix at order $T$ (resp. $N$ ) and $e_{T}$ is a column $(N, 1)$ vector with all its elements equal to 1 . It is a spatial panel data model with a spatially lagged dependent variable ${ }^{3}$. There are three possibilities for estimating this type of model. The first one is to consider that the elements of the vector of municipal effects, $\eta$, are fixed coefficients to be estimated jointly with $b$ and the vector of spatial autoregression coefficients, $\rho$. On theoretical grounds, this strategy may be accepted. Municipalities are fixed entities so that a larger sample is a sample with the same municipalities but additional periods; therefore, the set of coefficients to be estimated does not vary with the sample size, ensuring consistency. However, estimating the whole set of coefficients of this fixed effects model implies estimating 600 coefficients and may raise computational problems.

Alternatives strategies are to estimate a transformed model, using either the between municipalities or the within municipalities transformation. These transformations come from the following decomposition of every variable $y$

$$
y_{i t}=\bar{y}_{i}+\left(y_{i t}-\bar{y}_{i}\right)
$$

\footnotetext{
${ }^{3}$ This type of model is not very well documented in the spatial econometrics literature; see, however, Elhorst, 2003 and Anselin, Jayet and Le Gallo, 2007.
} 
where, for every municipality $i, \bar{y}_{i}=T^{-l} \sum y_{i, t}$ is the mean over all periods and $\left(y_{i t}-\bar{y}_{i}\right)$ is the deviation to the municipal mean at period $t$. Let us note that the $(N, 1)$ column vector of municipal means, $\bar{y}=\left(\bar{y}_{1}, \ldots, \bar{y}_{N}\right)$, may be written in matrix form as

$$
\bar{y}=T^{-1}\left(e_{T}^{\prime} \otimes I_{N}\right) y
$$

Then the matrix form of the previous decomposition is

$$
y=T^{-1}\left(e_{T} \otimes I_{N}\right) \bar{y}+\left[y-T^{-1}\left(e_{T} \otimes I_{N}\right) \bar{y}\right]=T^{-1}\left(e_{T} e_{T}^{\prime} \otimes I_{N}\right) y+\left[\left(I_{T}-T^{-1} e_{T} e_{T}^{\prime}\right) \otimes I_{N}\right] y
$$

The between municipalities transformation uses the first term of this decomposition, the municipal mean. For every municipality, the whole time series of the dependent and the explanatory variables are replaced by their mean over the whole period: starting from model (2), and pre-multiplying all the terms by the matrix $T^{-1}\left(e_{T}^{\prime} \otimes I_{N}\right)$, one gets

$$
\bar{\tau}=\alpha+W(\rho) \bar{\tau}+\bar{X} \beta+\eta+\bar{\varepsilon}
$$

where $\bar{\tau}=T^{-1}\left(e_{T}^{\prime} \otimes I_{N}\right) \tau$ is the vector of municipal mean tax rates, $\bar{X}=T^{-1}\left(e_{T}^{\prime} \otimes I_{N}\right) X$ is the vector of municipal means of the explanatory variables, and $\bar{\varepsilon}=T^{-1}\left(e_{T}^{\prime} \otimes I_{N}\right) \varepsilon$ is the vector of municipal mean residuals. The standard assumption that the municipal effects, are i.i.d. with variance $\sigma_{\eta}^{2}\left(V \eta=\sigma_{\eta}^{2} I_{N}\right)$ and are not correlated with the random terms, $\varepsilon_{i, t}$, also deemed to be i.i.d. with variance $\sigma_{\varepsilon}^{2}\left(V \varepsilon=\sigma_{\varepsilon}^{2} I_{N T}\right)$, implies that the random part of the between municipalities model is also i.i.d with variance $\sigma^{2}=\sigma_{\eta}^{2}+T^{-1} \sigma_{\varepsilon}^{2}: V(\eta+\bar{\varepsilon})=\sigma^{2} I_{N}$.

Alternatively, we can assume that the vector $\eta$ is spatially autoregressive

$$
\eta=W(\lambda) \eta+\zeta \Leftrightarrow \eta=\left(I_{N}-W(\lambda)\right)^{-1} \zeta
$$


where $\zeta$ is a vector of i.i.d. random terms $\left(V \eta=\sigma_{\zeta}^{2} I_{N}\right)$, so that

$$
V(\eta+\bar{\varepsilon})=\sigma_{\zeta}^{2}\left(I_{N}-W(\lambda)\right)^{-1}\left(I_{N}-W^{\prime}(\lambda)\right)^{-1}+\sigma_{\varepsilon}^{2} T^{-1} I_{N}
$$

In both cases, the between municipalities model can be estimated using standard maximum likelihood methods.

The between model focuses on mean differences across municipalities; it neglects time evolutions for each municipality. Conversely, with the within transformation, the mean differences across municipalities disappear and the analysis focuses on time evolutions.

The standard within municipalities transformation uses the second term of the decomposition, the deviation from the mean: starting from model (1'), and pre-multiplying all the terms by the matrix $\left\lfloor\left(I_{T}-T^{-1} e_{T} e_{T}^{\prime}\right) \otimes I_{N}\right\rfloor$, one gets:

$$
\Delta \tau=\left[I_{T} \otimes W(\rho)\right] \Delta \tau+\Delta X \beta+\Delta \varepsilon
$$

where $\Delta \tau=\left[\left(I_{T}-T^{-1} e_{T} e_{T}^{\prime}\right) \otimes I_{N}\right] \tau$ is the vector of deviations of tax rates to their municipal mean, $\Delta X=\left[\left(I_{T}-T^{-1} e_{T} e_{T}^{\prime}\right) \otimes I_{N}\right] X$ is the matrix of deviations of the explanatory variables to their municipal mean, $\Delta \varepsilon=\left\lfloor\left(I_{T}-T^{-1} e_{T} e_{T}^{\prime}\right) \otimes I_{N}\right\rfloor \varepsilon$ is the vector of deviations of residuals to their municipal mean.

The technical advantage of the within municipalities transformation is that the vector of municipal effects, $\eta$, disappears. It is well known that, when there is no spatial lag (the vector $\rho$ being zero, so that $W(\rho)=0)$, this model can be efficiently estimated using ordinary least squares. However, as noted by Anselin, Jayet and Le Gallo (2007), as soon as there is a spatially lagged endogenous variable, the standard within model can no longer be estimated by maximum likelihood. The reason is very simple: the residual terms are linked to each other by the equalities $\sum\left(\varepsilon_{i, t}-\bar{\varepsilon}_{i}\right)=0$ for all $i$, and then the variance-covariance matrix, $V(\Delta \varepsilon)=\sigma_{\varepsilon}^{2}\left[\left(I_{T}-T^{-1} e_{T} e_{T}^{\prime}\right) \otimes I_{N}\right]$ is not full rank. 
We overcome this problem using a variant of the within municipalities transformation where, instead of using deviations from the mean, we use deviations from a reference year; observations for that year are then deleted from the sample. For example, if the reference year is year 1 , this variant of the within municipalities transformation is

$$
D \tau=\left[I_{T} \otimes W(\rho)\right] D \tau+D X \beta+D \varepsilon
$$

where $D$ is the matrix

$$
D=\left[\begin{array}{ll}
-e_{N-1} & I_{N-1}
\end{array}\right]=\left[\begin{array}{cccccc}
-1 & 1 & 0 & \ldots & \ldots & 0 \\
\vdots & 0 & \ddots & \ddots & & \vdots \\
-1 & \vdots & \ddots & 1 & \ddots & \vdots \\
\vdots & \vdots & & \ddots & \ddots & 0 \\
-1 & 0 & \ldots & \ldots & 0 & 1
\end{array}\right]
$$

In equation (10), the variance-covariance matrix is full rank and the model can be estimated by maximum likelihood. Moreover, we are able to prove that ${ }^{4}$

- The ML estimators of the vectors $\rho$ and $\beta$ do not depend upon the reference year.

- If the vector $\rho$ equals zero, the ML (and GLS) estimator of $\beta$ is the standard OLS estimate of (6).

\subsubsection{Specifying the weights matrix}

The weights matrix, $W(\rho)$, is the matrix with current element $w_{i, j}(\rho)$. The line $i$ of $W$ is the set of weights used for calculating the spatial lag of municipality $i$. Usually, the weights matrix is assumed to be linear, $W(\rho)=\rho W^{1}$, where $W^{1}$ is row normalised, each row summing to unity, and the vector $\rho$ reduces to a scalar. Standard choices for $W^{1}$ are row normalised contiguity matrices (only the $k$ nearest neighbours have a positive weight), or weights inversely proportional to distance or to the square of the distance. The fact that the weights matrix is arbitrarily chosen is unsatisfactory, as different matrices may lead to

\footnotetext{
${ }^{4}$ Proofs are available on request from the authors
} 
different results. Therefore, some authors test several matrices, in order to assess the robustness of the conclusions. But, in most cases, only one matrix is used.

In this paper, we propose a more general formulation, the weights matrix $W(\rho)$ being a linear combination of partial weights:

$$
W(\rho)=\rho_{1} W^{1}+\cdots+\rho_{K} W^{K}
$$

where the vector of coefficients is $\rho=\left(\rho_{1}, \ldots, \rho_{K}\right)$ and each matrix $W^{1}, \ldots W^{K}$ corresponds to a specific type of interaction between municipalities. This formulation reduces to the standard one when $k=1$.

This specification of the weights matrix has been used twice. In a first stage, we used it to test the maximum distance separating two interacting municipalities. More precisely, for every municipality $i$, we sort all the other municipalities by increasing distance. Then, we build pseudo-contiguity matrices $C^{1}, \ldots, C^{9}$, such that $c_{i, j}^{k}=1$ if, after sorting by increasing distance to municipality $i$, municipality $j$ has a rank between a minimum $n_{-}^{k}$ and a maximum $n_{+}^{k}$, with

\begin{tabular}{|c|c|c|c|c|c|c|c|c|c|}
\hline Rank & 1 & 2 & 3 & 4 & 5 & 6 & 7 & 8 & 9 \\
\hline$n_{-}^{k}$ & 1 & 11 & 25 & 45 & 73 & 113 & 169 & 249 & 361 \\
\hline$n_{+}^{k}$ & 10 & 24 & 44 & 72 & 112 & 168 & 248 & 360 & 520 \\
\hline
\end{tabular}

Therefore, $c_{i, j}^{1}=1$ if municipality $j$ is among the ten municipalities closest to $i$; $c_{i, j}^{2}=1$ if municipality $j$ is not among the ten municipalities closest to $i$ but is among the 24 closest ones; and so on.

The choice of these thresholds implies that the number of nonzero elements of $C^{k}$ is roughly proportional to the square root of $k$, so that the distances covered by each matrix are roughly similar. Then, for every $k, W^{k}$ is obtained after a row normalisation of $C^{k}$. 


\subsubsection{Does language matter?}

In a second stage, we use a similar methodology for testing whether language matters for interactions between municipalities. More precisely, among the 589 Belgian municipalities, 335 are Flemish-speaking, 235 are French-speaking, and 19 - those of the Brussels region are bi-lingual. We test the hypothesis that the intensity of interactions is lower between two municipalities speaking different languages than between two municipalities speaking the same language.

For testing that hypothesis, for every $k$, we write $W^{k}$ as the sum of 5 sub-matrices

$$
W^{k}=W^{k, F F}+W^{k, W W}+W^{k, B B}+W^{k, F W}+W^{k, F B}
$$

where

- $\quad w_{i, j}^{k, F F}=w_{i, j}^{k}$ when both municipalities $i$ and $j$ are Flemish, zero otherwise,

- $w_{i, j}^{k, W W}=w_{i, j}^{k}$ when both municipalities $i$ and $j$ are Walloon, zero otherwise,

- $w_{i, j}^{k, B B}=w_{i, j}^{k}$ when both $i$ and $j$ are in the Brussels region, zero otherwise,

- $\quad w_{i, j}^{k, F W}=w_{i, j}^{k}$ when $i$ is Flemish (resp. Walloon) and $j$ is Walloon (resp. Flemish), zero otherwise,

- $\quad w_{i, j}^{k, F B}=w_{i, j}^{k}$ when $i$ is Flemish (resp. in the Brussels region) and $j$ is in the Brussels (resp. Flemish), zero otherwise,

To sum up, $W^{k, F F}, W^{k, W W}$ and $W^{k, B B}$, correspond to interactions within the same region, respectively Flanders, Wallonia and Brussels; while $W^{k, F W}$ and $W^{k, B W}$ correspond to interactions between Flanders and the other two regions, Wallonia and Brussels respectively ${ }^{5}$.

\footnotetext{
${ }^{5}$ Note that we do not include interactions between the Brussels and Walloon municipalities since Brussels is completely surrounded by Flemish municipalities.
} 
Therefore, the full weights matrix takes the following form

$$
W(\rho)=\sum_{k}\left(\rho_{k, F F} W^{k, F F}+\rho_{k, W W} W^{k, W W}+\rho_{k, B B} W^{k, B B}+\rho_{k, F W} W^{k, F W}+\rho_{k, F B} W^{k, F B}\right)
$$

\subsection{Data set}

We estimate equations (1), (2) and (6), using annual data for the 589 Belgian municipalities over the period 1985-2004. These data have been collected by Richard, Tulkens and Verdonck (2002) and by Van Parys and Verbecke (2006). The main data sources are the National Institute of Statistics, the Department of Economics and the Department of Geography of the Université Catholique de Louvain, in Louvain-la-Neuve. Table 2 reports the summary statistics.

As noted above, local tax policies also reflect the impact of differences in economic and demographic factors grouped in the vector $X$ in equation (1). Following the empirical literature, we include a set of socio-demographic variables, such as the unemployment rate, the population density and per capita income. These three variables may be interpreted as expenditure needs variables. We thus expect a positive sign for the respective corresponding parameters. We also include three electoral dummies to check the existence of an electoral cycle, i.e. lower tax rates the years around the election year and higher tax rates in the middle of the legislative period, which last for six years - elections occurred in the last quarter of 1988, 1994 and 2000 respectively. Finally we include a trend variable.

Table 1 displays standard summary statistics for the two explained variables and the three main explanatory variables. Table 2 provides a decomposition of the variance of these variables using the two dimensions introduced above, within and between municipalities. For the local income tax, the local property tax, and the unemployment rate, differences across municipalities are the main source of variability; differences across time also exist, but they are a minor source of variability. 
Table 1 - Summary statistics

\begin{tabular}{|l|l|l|l|l|}
\hline Variable & Mean & Standard dev. & Min & Max \\
\hline Local income tax & 6.84 & 1.07 & 0 & 10 \\
\hline Local property tax & 2633.51 & 689,67 & 293.75 & 5750 \\
\hline Population density & 6.71 & 17.42 & 0.19 & 201.96 \\
\hline Per capita income & 350.45 & 101.92 & 147 & 704.86 \\
\hline Unemployment rate & 3.60 & 1.85 & 0 & 21.51 \\
\hline
\end{tabular}

Note: Number of observations: $11780(\mathrm{~T}=20, \mathrm{~N}=589)$

Table 2 - Variance disaggregation

\begin{tabular}{|l|l|l|l|l|}
\hline Variable & Total & Within & Between & $\begin{array}{l}\text { variance within in } \\
\text { of variance }\end{array}$ \\
\hline Local income tax & 0.0451 & 0.011 & 0.0342 & 24.3 \\
\hline Local property tax & 0.0859 & 0.0264 & 0.0595 & 30.7 \\
\hline Population density & 1.37 & 0.002 & 1.37 & 0.1 \\
\hline Income per capita & 0.084 & 0.065 & 0.019 & 77.4 \\
\hline Unemployment rate & 0.274 & 0.065 & 0.208 & 23.9 \\
\hline
\end{tabular}

\section{Results}

Both the within and the between transformed models have been estimated using the weights matrices presented in section 2.2. Estimations have been carried out using maximum likelihood. Due to the complexity of the structure of the weights matrix, we systematically tested for the inclusion of coefficients, using a top down approach: interaction effects between municipalities were not included when, after a Wald test, the hypothesis of a zero coefficient has been accepted.

For both the within and the between model, we started with a general specification where spatially autoregressive effects are included for both the endogenous variable and the error term.

We estimated that model in two stages. In the first stage, using equation (9), we took into account distances between municipalities without any distinction between regions; the results are summarized in Table 3. In the second stage, we used the results of the first stage as well as equation (14) to investigate the differences across regions; results are reported in 
Table 4. Finally, we examined the impact of control variables, like population density, unemployment rate and per capita income, as well as the direction of the trend - see Table 5 in the main text and Table 6 in Appendix.

\subsection{Without interregional differences}

Those results have several interesting implications. Prior to their examination, remember that, though the within model copes with year to year evolution for each municipality, the between model focuses on differences from the mean, across municipalities and over the whole twenty year period.

First of all, there is a striking difference between the estimation results of the within model and the between model.

The within model confirms the existence of strategic interactions across municipalities, the coefficients of the autoregressive terms for the endogenous variable being highly significant. The between model suggests the opposite conclusion: no autoregressive term for the endogenous variable has a significant effect so that there is no interaction across municipalities.

The second implication is that, for the within model, interactions are limited to municipalities which are close to each other.

Given that the matrices $W^{1}$ to $W^{4}$ correspond to the 72 closest neighbours at most and that there are 589 municipalities in Belgium, each Belgian municipality interacts with around its ten per cent closest neighbours.

The absence of interactions between municipalities in the between model implies that the mean tax level of a municipality is not influenced by the mean tax level of its neighbours. However, the fact that there are significantly positive interactions in the within model 
implies that municipalities react to tax changes decided by their neighbours: if next door municipality $j$ decreases its tax rate, municipality $i$ also decreases its own rate.

Table 3 - Autoregressive effects and proximity

\begin{tabular}{|c|c|c|c|c|c|c|}
\hline $\begin{array}{c}\text { Interaction } \\
\text { matrix }\end{array}$ & & & $w^{1}$ & $w^{2}$ & $w^{3}$ & $w^{A}$ \\
\hline \multirow{4}{*}{$\begin{array}{l}\text { Within } \\
\text { model }\end{array}$} & \multirow{2}{*}{$\begin{array}{l}\text { Local Income Tax } \\
\text { (LIT) }\end{array}$} & $\begin{array}{c}\text { Endogenous } \\
\text { variable }\end{array}$ & $0.359 * *$ & $0.090 * *$ & $0.062^{*}$ & $0.087^{*}$ \\
\hline & & Error Term & & & & \\
\hline & \multirow{2}{*}{$\begin{array}{l}\text { Local Property Tax } \\
\text { (LPT) }\end{array}$} & $\begin{array}{c}\text { Endogenous } \\
\text { variable }\end{array}$ & $0.142^{*}$ & $0.283^{* *}$ & $0.118^{* *}$ & \\
\hline & & Error Term & $0.185^{* *}$ & & & \\
\hline \multirow{4}{*}{$\begin{array}{l}\text { Between } \\
\text { model }\end{array}$} & \multirow{2}{*}{$\begin{array}{l}\text { Local Income Tax } \\
\text { (LIT) }\end{array}$} & $\begin{array}{c}\text { Endogenous } \\
\text { variable }\end{array}$ & & & & \\
\hline & & Error Term & $0.300 * *$ & & & \\
\hline & \multirow{2}{*}{$\begin{array}{l}\text { Local Property Tax } \\
\text { (LPT) }\end{array}$} & $\begin{array}{c}\text { Endogenous } \\
\text { variable }\end{array}$ & & & & \\
\hline & & Error Term & $0.361 * *$ & $0.408 * *$ & & \\
\hline
\end{tabular}

Notes: Coefficients not significantly different from zero at the $5 \%$ level have been omitted.

$*$ : $10 \%$ significant, $* *$ : $5 \%$ significant, $* * *$ : $1 \%$ significant.

\subsection{The role of interregional differences, or languages matter}

In the second stage, we use the results of the first stage as well as equation (14) to investigate the differences across regions. More precisely, for every matrix $W^{k}$ with a significant effect in the previous subsection, we tested and, when relevant, estimated the decomposition given by equation (14). Since there are no interaction between municipalities in the between model, there is no need to analyse how these interactions vary across regions, so that the analysis is carried out for the within model only and the results are displayed in Table 4. There was no regional decomposition of $W^{3}$ for the local property tax and of $W^{4}$ for the local income tax, as statistical tests accepted the null hypothesis of no differences between regions.

Our main result shows that there are significant differences between the three regions. For the local income tax, the interaction of a municipality with its closest neighbours is much higher in Brussels and Wallonia than in Flanders. The elasticity of the local income tax rate to the average rate over its closest neighbours amounts to 0.5 in Brussels and Wallonia, while it 
is only 0.2 in Flanders. For both Brussels and Flanders, the elasticity of the local property tax to the average rate of the closest neighbours is 0.2 .

Another important result comes from the comparison of the interactions between municipalities located in the same region and the interactions between municipalities located in different regions. A Wald test shows that, for the local income tax, the interactions between Flemish municipalities and municipalities located in the other regions are significantly weaker than the interactions between municipalities located in the same region. The same test shows that this difference does not hold for the local property tax.

Table 4 - Interactions between municipalities: interregional differences

\begin{tabular}{|c|c|c|c|c|}
\hline Type of interaction & $\begin{array}{l}\text { Proximity } \\
\text { rank }\end{array}$ & Matrix $^{6}$ & $\begin{array}{l}\text { Local Income } \\
\text { Tax (LIT) }\end{array}$ & $\begin{array}{l}\text { Local Property } \\
\text { Tax (LPT) }\end{array}$ \\
\hline \multirow{4}{*}{ Within Flanders } & $1-10$ & $W^{1, F F}$ & $0.189 * *$ & \\
\hline & $11-24$ & $W^{2, F F}$ & 0.061 & \\
\hline & $25-44$ & $W^{3, F F}$ & $0.208^{* *}$ & \\
\hline & $1-24$ & $W^{1, F F}+W^{2, F F}$ & & $0.221 * *$ \\
\hline \multirow{4}{*}{ Within Wallonia } & $1-10$ & $W^{1, W W}$ & $0.478 * *$ & \\
\hline & $11-24$ & $W^{2, W W}$ & 0,076 & \\
\hline & $25-44$ & $W^{3, W W}$ & $-0,0297$ & \\
\hline & $1-24$ & $W^{1, W W}+W^{2, W W}$ & & $0.168 * *$ \\
\hline Within Brussels & $1-24$ & $W^{4}$ & $0,520 * *$ & $0.213^{*}$ \\
\hline $\begin{array}{l}\text { Between Flanders and the } \\
\text { other two regions }{ }^{7}\end{array}$ & $1-10$ & $W^{1, F B}+W^{1, F W}$ & $0.171^{* *}$ & $0.211^{* *}$ \\
\hline All regions & $25-44$ & $W^{3}$ & & $0.164^{* *}$ \\
\hline All regions & $45-72$ & $W^{4}$ & $0.112^{* *}$ & \\
\hline
\end{tabular}

Notes: Coefficients without asterisk are not significantly different from zero at the $5 \%$ level.

$*$ : $5 \%$ significant, $* *$ : $1 \%$ significant.

\footnotetext{
${ }^{6}$ When there is no significant differences between the coefficients estimated for two matrices, these two matrices have been grouped. For example, if the hypothesis $\rho^{1, F F}=\rho^{2, F F}$ can be accepted, then instead of using $\rho^{1, F F} W^{1, F F}+\rho^{2, F F} W^{2, F F}$ we use a single coefficient multiplying $W^{1, F F}+W^{2, F F}$. Therefore, all the 24 closest municipalities have the same impact.

${ }^{7}$ There is no significant difference between Brussels and Wallonia regarding interactions with Flanders. We did not introduce interactions between Wallonia and Brussels since Brussels Region is entirely surrounded by Flemish municipalities.
} 


\subsection{The impact of control variables and the direction of the trend}

Finally, Table 5 shows the estimation results for the four models, i.e. with the local income tax and the local property tax as endogenous variables and using the within and the between transformations, with spatial dependence. Table 6, in Appendix, shows the same results when there is no spatial dependence. Differences between the two sets of estimations are not important.

Table 5 - ML estimation results of within and between models (with spatial lag dependence)

\begin{tabular}{|c|c|c|c|c|}
\hline \multirow{2}{*}{$\begin{array}{l}\text { Dependent var. } \\
\text { Estimator }\end{array}$} & \multicolumn{2}{|c|}{ Local Income Tax (LIT) } & \multicolumn{2}{|c|}{ Local Property Tax (LPT) } \\
\hline & Within & Between & Within & Between \\
\hline Population density & $\begin{array}{l}0.023 \\
(0.615)\end{array}$ & $\begin{array}{l}0.016 * \\
(3.42)\end{array}$ & $\begin{array}{l}0.022 \\
(0.386)\end{array}$ & $\begin{array}{l}0.001 \\
(0.00)\end{array}$ \\
\hline Unemployment rate & $\begin{array}{l}0.015^{* * *} \\
(15.9)\end{array}$ & $\begin{array}{l}0.080^{* * * *} \\
(12.8)\end{array}$ & $\begin{array}{l}-0.024 * * * \\
(28.3)\end{array}$ & $\begin{array}{l}0.196^{* * * *} \\
(33.1)\end{array}$ \\
\hline Income per capita & $\begin{array}{l}0.099 * * * \\
(23.4)\end{array}$ & $\begin{array}{l}-0.265^{* * *} \\
(12.5)\end{array}$ & $\begin{array}{l}0.060 * * \\
(5.48)\end{array}$ & $\begin{array}{l}-0.331^{* * *} \\
(15.2)\end{array}$ \\
\hline Election year $\mathrm{t}-1$ & $\begin{array}{l}-0.011 * * * \\
(17.1)\end{array}$ & & $\begin{array}{l}-0.013^{* * *} \\
(16.1)\end{array}$ & \\
\hline Election year $\mathrm{t}$ & $\begin{array}{l}-0.016^{* * *} \\
(39.7)\end{array}$ & & $\begin{array}{l}-0.024 * * * \\
(53.0)\end{array}$ & \\
\hline Election year $t+1$ & $\begin{array}{l}-0.008 * * * \\
(10.1)\end{array}$ & & $\begin{array}{l}-0.017^{* * *} \\
(27.8)\end{array}$ & \\
\hline Trend & $\begin{array}{l}-0.002^{*} \\
(4.2)\end{array}$ & & $\begin{array}{l}0.006^{* * * *} \\
(31.8)\end{array}$ & \\
\hline Intercept & & $\begin{array}{l}3.34 * * * \\
(56.4)\end{array}$ & & $\begin{array}{l}4.92 * * * \\
(91.8)\end{array}$ \\
\hline Initial log likelihood & 9780 & -693 & 8221 & -795 \\
\hline Final log likelihood & 10202 & -688 & 8784 & -696 \\
\hline Observations & 11191 & 589 & 11191 & 589 \\
\hline
\end{tabular}

Notes: ${ }^{*}: 10 \%$ significant, ${ }^{* *}: 5 \%$ significant, ${ }^{* * *}: 1 \%$ significant; Wald statistics between brackets; variables are log-transformed (except dummies and trend).

We obtain the expected positive sign for the population density but, in most cases, it is not significant. As for the unemployment rate, apart for the within estimator on the local property tax, we get a positive sign highlighting the fact that unemployed people call for some extra local expenditures - in Belgium part of the initiatives against unemployment are under the responsibility of the municipalities, like the local agencies for employment - that 
might increase local taxation. The parameter associated with income per capita is positive for both local tax rates in the within model, as in the empirical literature where the demand for public services is very often positively correlated with income. It is however negative in the between model, supporting the view that higher income municipalities can obtain the same amount of revenues with smaller rates. Dummy variables for the years around election years seem to support the view of an electoral cycle. Finally, we get a negative sign for the trend in the local income tax but a positive sign for the local property tax which is in line with the view of putting the tax burden on the more immobile tax base and to non-voting persons as well (remember that owners pay that tax where the good is located, not where they vote).

\section{Conclusion}

In this paper, we first show that Belgian municipalities interact with each other over the two main local tax rates, the local surcharge on the individual income tax, which is primarily a local tax on labour income, and the local surcharge on the property tax. That first result is consistent with those of previous studies, especially Heyndels and Vuchelen (1998), which proposes a cross section analysis, and Richard, Tulkens and Verdonck (2002), which, on the same period, uses a dynamic model where the slope of the reaction function is not directly estimated. Using tools of spatial econometrics and an original methodology for specifying weights matrices, we find out that municipalities are sensitive to tax rates set by their close neighbours only.

Second, we explore the effects of the proximity in terms of language on the empirical evidence of tax interdependence. Then, we reject the hypothesis that the language does not matter for interactions among nearby jurisdictions. Especially, for the local income tax rate, in the within model, the intensity of interactions is shown to be lower between municipalities speaking different languages than between municipalities speaking the same language. That observation is particularly relevant for today Belgium and might be viewed as a contribution to the ongoing debate on the regionalisation of some taxes. 
In that prospect, the fact that the difference in terms of interaction occurs for the local income tax, which is levied on a residence principle, rather than for the tax on immovable property, levied on a source base, is per se an interesting result; it supports the view that providing the regions with more fiscal autonomy is less likely to generate externalities if that autonomy focuses on a tax levied according to the residence principle and related to the personal taxpayer location decision than on a tax levied according to the source principle and related to the location decision of taxpayer's wealth.

\section{References}

Anselin L., Jayet H. and Le Gallo J. (2007), "Spatial Econometrics and Panel Data Models", in L. Matyas and P. Sevestre (eds), Handbook of Panel Data Econometrics, Kluwer.

Besley T. and Case A. (1995), "Incumbent behaviour: Vote seeking, tax setting and yardstick competition", American Economic Review, 85, 25-45.

Bordignon M., Cerniglia F. and Revelli F. (2003), "In search of yardstick competition: A spatial analysis of Italian municipality property tax setting", Journal of Urban Economics, 54, 199-217.

Brett C. and Pinske J. (2000), "The determinants of municipal tax rates in British Columbia", Canadian Journal of Economics, 33, 695-714.

Brueckner J.K. (1996), "Testing for strategic interaction among local governments: The case of growth controls", Journal of Urban Economics, 44(3), 438-467.

Brueckner J.K. (2003), "Strategic interaction among governments: An overview of empirical studies", International Regional Science Review, 26, 175-188.

Brueckner J.K. and Saavedra L. (2001), "Do local governments engage in strategic property-tax competition?", National Tax Journal, 54, 203-229.

Buettner T. (2001), "Local business taxation and competition for capital: The choice of the tax rate", Regional Science and Urban Economics, 31, 215-245.

Case A.C. (1993), "Interstate tax competition after TRA86", Journal of Policy Analysis and Management, 12, 136-148.

Charlot S. and S. Paty (2007), "Market access effect and local tax setting: Evidence from a French panel data", Journal of Economic Geography, 7, 247-263.

Elhorst J.P. (2003), "Specification and estimation of spatial panel data models", International Regional Science Review, 26(3), pp. 244-268.

Feld L.P, Josselin J.M. and Rocaboy Y. (2002), "Le mimétisme fiscal : une application aux régions françaises", Economie et Prévision, vol. 156(5), pp. 43-49.

Feld L. P. and Reulier E. (2005), "Strategic tax competition in Switzerland: Evidence from a panel of the Swiss Cantons", CESifo Working Paper series, 1516.

Gérard, M., 2002, "Fiscal Federalism in Belgium ", in Commission on Fiscal Imbalance, A new division of Canada's Financial Resources Report, Supporting document 3, Québec Provincial Government, 175-194. 
Heyndels B. and Vuchelen J. (1998), "Tax mimicking among Belgian municipalities", National Tax Journal, 51, 89-101.

Ladd H.F. (1992), " Mimicking of local tax burdens among neighbouring, countries ", Public Finance Quarterly, 20(4), 450-67.

Leprince M., Madiès T. and Paty S. (2007), "Business tax interactions among local governments: An empirical analysis of local tax setting in France", Journal of Regional Science, 47, 603-621.

Revelli F. (2005), "On spatial public finance empirics", International Tax and Public Finance, 12(4), 475-492.

Richard J-F, H Tulkens and M Verdonck (2002), "Dynamique des interactions fiscales entre les communes belges 1984-1997", Economie et Prévision, 156, 1-14.

Salmon P. (1987), "Decentralization as an incentive scheme", Oxford Review of Economic Policy, 3, 24-43.

Solé-Ollé A. (2003), "Electoral accountability and tax mimicking: the effects of electoral margins, coalition government, and ideology", European Journal of Political Economy, 19, 685-713.

Van Parys S. and Verbecke T. (2006), "Tax competition among Belgian Municipalities: a multidimensional battle?", University of Ghent, mimeo.

Wildasin D. (1988), "Nash Equilibria in Models of Fiscal Competition", Journal of Public Economics, $35(2), 229-240$.

Wilson J. D. (1986), "A Theory of Interregional Tax Competition", Journal of Urban Economics, 19, 296-315.

Wilson J.D. (1999), "Theories of tax competition", National Tax Journal, 52, 269-304.

Zodrow G. and Mieszkowski P. (1986), "Pigou, Tiebout, Poperty Taxation, and the Underprovision of Local Public Goods", Journal of Urban Economics, 19, 356-370. 


\section{Appendix}

Table 6: OLS estimation results of within and between models

(without spatial lag dependence)

\begin{tabular}{|c|c|c|c|c|}
\hline \multirow{2}{*}{$\begin{array}{l}\text { Dependent var. } \\
\text { Estimator }\end{array}$} & \multicolumn{2}{|c|}{ Local Income Tax (LIT) } & \multicolumn{2}{|c|}{ Local Property Tax (LPT) } \\
\hline & Within & Between & Within & Between \\
\hline Population density & $\begin{array}{l}0 \\
(0)\end{array}$ & $\begin{array}{l}0.016 * * \\
(2.36)\end{array}$ & $\begin{array}{l}0 \\
(0)\end{array}$ & $\begin{array}{l}0.048 * * * \\
(5.73)\end{array}$ \\
\hline Unemployment rate & $\begin{array}{l}0.033^{* * *} \\
(8.2)\end{array}$ & $\begin{array}{l}0.079 * * * \\
(4.43)\end{array}$ & $\begin{array}{l}-0.062^{* * *} \\
(-13.4)\end{array}$ & $\begin{array}{l}0.070 * * * \\
(3.32)\end{array}$ \\
\hline Per capita income & $\begin{array}{l}0.166^{* * *} \\
(7.72)\end{array}$ & $\begin{array}{l}-0.247^{* * *} \\
(-3.78) \\
\end{array}$ & $\begin{array}{l}0.207^{* * *} \\
(8.4)\end{array}$ & $\begin{array}{l}-0.861 * * * \\
(-11.1)\end{array}$ \\
\hline Election year t-1 & $\begin{array}{l}-0.022^{* * *} \\
(-8.27)\end{array}$ & - & $\begin{array}{l}-0.026 * * * \\
(-8.29)\end{array}$ & - \\
\hline Election year $\mathrm{t}$ & $\begin{array}{l}-0.036 * * * \\
(-13.5)\end{array}$ & - & $\begin{array}{l}-0.048^{* * *} \\
(-15.5)\end{array}$ & - \\
\hline Election year $\mathrm{t}+1$ & $\begin{array}{l}-0.018 * * * \\
(-6.9)\end{array}$ & - & $\begin{array}{l}-0.036^{* * *} \\
(-11.8)\end{array}$ & - \\
\hline Trend & $\begin{array}{l}-0.001^{*} \\
(-1.57)\end{array}$ & - & $\begin{array}{l}0.009 * * * \\
(8.88)\end{array}$ & - \\
\hline Intercept & - & $\begin{array}{l}3.23^{* * *} \\
(8.38)\end{array}$ & - & $\begin{array}{l}8.11^{* * *} \\
(17.7)\end{array}$ \\
\hline Log lik. & 9780 & -693 & 8221 & -796 \\
\hline Observations & 11191 & 589 & 11191 & 589 \\
\hline
\end{tabular}

Notes: $*: 10 \%$ significant, ${ }^{* *}: 5 \%$ significant, $* * *: 1 \%$ significant. T-statistics in parentheses. Variables are logtransformed (except dummies and trend). 


\section{CESifo Working Paper Series}

for full list see www.cesifo-group.org/wp

(address: Poschingerstr. 5, 81679 Munich, Germany, office@cesifo.de)

2493 Christian Bruns and Oliver Himmler, It's the Media, Stupid - How Media Activity Shapes Public Spending, December 2008

2494 Andreas Knabe and Ronnie Schöb, Minimum Wages and their Alternatives: A Critical Assessment, December 2008

2495 Sascha O. Becker, Peter H. Egger, Maximilian von Ehrlich and Robert Fenge, Going NUTS: The Effect of EU Structural Funds on Regional Performance, December 2008

2496 Robert Dur, Gift Exchange in the Workplace: Money or Attention?, December 2008

2497 Scott Alan Carson, Nineteenth Century Black and White US Statures: The Primary Sources of Vitamin D and their Relationship with Height, December 2008

2498 Thomas Crossley and Mario Jametti, Pension Benefit Insurance and Pension Plan Portfolio Choice, December 2008

2499 Sebastian Hauptmeier, Ferdinand Mittermaier and Johannes Rincke, Fiscal Competition over Taxes and Public Inputs: Theory and Evidence, December 2008

2500 Dirk Niepelt, Debt Maturity without Commitment, December 2008

2501 Andrew Clark, Andreas Knabe and Steffen Rätzel, Boon or Bane? Others' Unemployment, Well-being and Job Insecurity, December 2008

2502 Lukas Menkhoff, Rafael R. Rebitzky and Michael Schröder, Heterogeneity in Exchange Rate Expectations: Evidence on the Chartist-Fundamentalist Approach, December 2008

2503 Salvador Barrios, Harry Huizinga, Luc Laeven and Gaëtan Nicodème, International Taxation and Multinational Firm Location Decisions, December 2008

2504 Andreas Irmen, Cross-Country Income Differences and Technology Diffusion in a Competitive World, December 2008

2505 Wenan Fei, Claude Fluet and Harris Schlesinger, Uncertain Bequest Needs and LongTerm Insurance Contracts, December 2008

2506 Wido Geis, Silke Uebelmesser and Martin Werding, How do Migrants Choose their Destination Country? An Analysis of Institutional Determinants, December 2008

2507 Hiroyuki Kasahara and Katsumi Shimotsu, Sequential Estimation of Structural Models with a Fixed Point Constraint, December 2008

2508 Barbara Hofmann, Work Incentives? Ex Post Effects of Unemployment Insurance Sanctions - Evidence from West Germany, December 2008 
2509 Louis Hotte and Stanley L. Winer, The Demands for Environmental Regulation and for Trade in the Presence of Private Mitigation, December 2008

2510 Konstantinos Angelopoulos, Jim Malley and Apostolis Philippopoulos, Welfare Implications of Public Education Spending Rules, December 2008

2511 Robert Orlowski and Regina T. Riphahn, The East German Wage Structure after Transition, December 2008

2512 Michel Beine, Frédéric Docquier and Maurice Schiff, International Migration, Transfers of Norms and Home Country Fertility, December 2008

2513 Dirk Schindler and Benjamin Weigert, Educational and Wage Risk: Social Insurance vs. Quality of Education, December 2008

2514 Bernd Hayo and Stefan Voigt, The Relevance of Judicial Procedure for Economic Growth, December 2008

2515 Bruno S. Frey and Susanne Neckermann, Awards in Economics - Towards a New Field of Inquiry, January 2009

2516 Gregory Gilpin and Michael Kaganovich, The Quantity and Quality of Teachers: A Dynamic Trade-off, January 2009

2517 Sascha O. Becker, Peter H. Egger and Valeria Merlo, How Low Business Tax Rates Attract Multinational Headquarters: Municipality-Level Evidence from Germany, January 2009

2518 Geir H. Bjønnes, Steinar Holden, Dagfinn Rime and Haakon O.Aa. Solheim, ,Large' vs. ,Small' Players: A Closer Look at the Dynamics of Speculative Attacks, January 2009

2519 Jesus Crespo Cuaresma, Gernot Doppelhofer and Martin Feldkircher, The Determinants of Economic Growth in European Regions, January 2009

2520 Salvador Valdés-Prieto, The 2008 Chilean Reform to First-Pillar Pensions, January 2009

2521 Geir B. Asheim and Tapan Mitra, Sustainability and Discounted Utilitarianism in Models of Economic Growth, January 2009

2522 Etienne Farvaque and Gaël Lagadec, Electoral Control when Policies are for Sale, January 2009

2523 Nicholas Barr and Peter Diamond, Reforming Pensions, January 2009

2524 Eric A. Hanushek and Ludger Woessmann, Do Better Schools Lead to More Growth? Cognitive Skills, Economic Outcomes, and Causation, January 2009

2525 Richard Arnott and Eren Inci, The Stability of Downtown Parking and Traffic Congestion, January 2009 
2526 John Whalley, Jun Yu and Shunming Zhang, Trade Retaliation in a Monetary-Trade Model, January 2009

2527 Mathias Hoffmann and Thomas Nitschka, Securitization of Mortgage Debt, Asset Prices and International Risk Sharing, January 2009

2528 Steven Brakman and Harry Garretsen, Trade and Geography: Paul Krugman and the 2008 Nobel Prize in Economics, January 2009

2529 Bas Jacobs, Dirk Schindler and Hongyan Yang, Optimal Taxation of Risky Human Capital, January 2009

2530 Annette Alstadsæter and Erik Fjærli, Neutral Taxation of Shareholder Income? Corporate Responses to an Announced Dividend Tax, January 2009

2531 Bruno S. Frey and Susanne Neckermann, Academics Appreciate Awards - A New Aspect of Incentives in Research, January 2009

2532 Nannette Lindenberg and Frank Westermann, Common Trends and Common Cycles among Interest Rates of the G7-Countries, January 2009

2533 Erkki Koskela and Jan König, The Role of Profit Sharing in a Dual Labour Market with Flexible Outsourcing, January 2009

2534 Tomasz Michalak, Jacob Engwerda and Joseph Plasmans, Strategic Interactions between Fiscal and Monetary Authorities in a Multi-Country New-Keynesian Model of a Monetary Union, January 2009

2535 Michael Overesch and Johannes Rincke, What Drives Corporate Tax Rates Down? A Reassessment of Globalization, Tax Competition, and Dynamic Adjustment to Shocks, February 2009

2536 Xenia Matschke and Anja Schöttner, Antidumping as Strategic Trade Policy Under Asymmetric Information, February 2009

2537 John Whalley, Weimin Zhou and Xiaopeng An, Chinese Experience with Global 3G Standard-Setting, February 2009

2538 Claus Thustrup Kreiner and Nicolaj Verdelin, Optimal Provision of Public Goods: A Synthesis, February 2009

2539 Jerome L. Stein, Application of Stochastic Optimal Control to Financial Market Debt Crises, February 2009

2540 Lars P. Feld and Jost H. Heckemeyer, FDI and Taxation: A Meta-Study, February 2009

2541 Philipp C. Bauer and Regina T. Riphahn, Age at School Entry and Intergenerational Educational Mobility, February 2009 
2542 Thomas Eichner and Rüdiger Pethig, Carbon Leakage, the Green Paradox and Perfect Future Markets, February 2009

2543 M. Hashem Pesaran, Andreas Pick and Allan Timmermann, Variable Selection and Inference for Multi-period Forecasting Problems, February 2009

2544 Mathias Hoffmann and Iryna Shcherbakova, Consumption Risk Sharing over the Business Cycle: the Role of Small Firms' Access to Credit Markets, February 2009

2545 John Beirne, Guglielmo Maria Caporale, Marianne Schulze-Ghattas and Nicola Spagnolo, Volatility Spillovers and Contagion from Mature to Emerging Stock Markets, February 2009

2546 Ali Bayar and Bram Smeets, Economic and Political Determinants of Budget Deficits in the European Union: A Dynamic Random Coefficient Approach, February 2009

2547 Jan K. Brueckner and Anming Zhang, Airline Emission Charges: Effects on Airfares, Service Quality, and Aircraft Design, February 2009

2548 Dolores Messer and Stefan C. Wolter, Money Matters - Evidence from a Large-Scale Randomized Field Experiment with Vouchers for Adult Training, February 2009

2549 Johannes Rincke and Christian Traxler, Deterrence through Word of Mouth, February 2009

2550 Gabriella Legrenzi, Asymmetric and Non-Linear Adjustments in Local Fiscal Policy, February 2009

2551 Bruno S. Frey, David A. Savage and Benno Torgler, Surviving the Titanic Disaster: Economic, Natural and Social Determinants, February 2009

2552 Per Engström, Patrik Hesselius and Bertil Holmlund, Vacancy Referrals, Job Search, and the Duration of Unemployment: A Randomized Experiment, February 2009

2553 Giorgio Bellettini, Carlotta Berti Ceroni and Giovanni Prarolo, Political Persistence, Connections and Economic Growth, February 2009

2554 Steinar Holden and Fredrik Wulfsberg, Wage Rigidity, Institutions, and Inflation, February 2009

2555 Alexander Haupt and Tim Krieger, The Role of Mobility in Tax and Subsidy Competition, February 2009

2556 Harald Badinger and Peter Egger, Estimation of Higher-Order Spatial Autoregressive Panel Data Error Component Models, February 2009

2557 Christian Keuschnigg, Corporate Taxation and the Welfare State, February 2009

2558 Marcel Gérard, Hubert Jayet and Sonia Paty, Tax Interactions among Belgian Municipalities: Does Language Matter?, February 2009 